\title{
Shade nets and substrates in seedling production of Annona squamosa L. in the Roraima Cerrado
}

\section{Malhas fotoconversoras e substratos na produção de mudas de Annona squamosa L. no Cerrado de Roraima}

\author{
Roberto Tadashi Sakazaki'; Wellington Farias Araújo²; João Luiz Lopes Monteiro \\ Neto $^{1 *}$; Pollyana Cardoso Chagas 3 ; Edvan Alves Chagas ${ }^{4}$; Hipólito Murga-Orrillo \\ Ricardo Manuel Bardales-Lozano ${ }^{6}$; Carlos Abanto-Rodríguez ${ }^{7}$
}

\begin{abstract}
Sugar apple (Annona squamosa L.) is one of the most widely grown member of the Annonaceae family in several regions, but there is still a lack of agronomic data regarding the management of its initial growth stages under Cerrado conditions. The aim of the present study was to evaluate the production of Annona squamosa L. seedlings under different environmental conditions achieved by using shade nets (E1: ChromatiNet ${ }^{\circledR}$ Silver 50\%; E2: ChromatiNet $^{\circledR}$ red 50\%; E3: ChromatiNet $^{\circledR}$ red 35\%; E4: ChromatiNet ${ }^{\circledR}$ Silver 35\%) in combination with four different substrates (S1: soil + sand + chicken manure; S2: soil + sand + cattle manure; S3: soil + sand + cattle manure + chicken manure; S4: soil + sand + sheep manure). An experiment was set up using a completely randomized design with treatments in a split-plot arrangement, with four replicates and ten plants per experimental unit. Seedling growth parameters and quality indices were evaluated. The tested environments had higher local temperatures relative to the external environment, which had a negative effect on plant growth. Environment E2 resulted in the highest plant height and dry weight, but led to uneven growth among the evaluated plant parts. The substrate with sheep manure (S4) did not benefit seedling production. The best results for seedling growth and quality were obtained with substrates S2 (soil + sand + cattle manure) and S3 (soil + sand + cattle manure + chicken manure), which are therefore promising for Annona squamosa L. seedling production in the Roraima Cerrado.
\end{abstract}

Key words: Annonaceae. Propagation. Shading screens.

\section{Resumo}

A ata (Annona squamosa L.) é uma das anonáceas mais cultivadas em várias regiões, porém ainda carece de informações agronômicas inerentes ao manejo nas fases iniciais de crescimento nas condições de Cerrado. Com isso, objetivou-se com este trabalho avaliar a produção de mudas de Annona squamosa L. em diferentes ambientes constituídos com malhas fotoconversoras [(A1) ChromatiNet ${ }^{\circledR}$ Silver 50\%;

\footnotetext{
' Discentes, Curso de Doutorado, Programa de Pós-Graduação em Agronomia, Universidade Federal de Roraima, POSAGRO/ UFRR, Boa Vista, RR, Brasil. E-mail: sakazakitadashi@gmail.com; joao.monteiro.neto@hotmail.com

2 Prof. Titular, Universidade Federal de Roraima, UFRR, Boa Vista, RR, Brasil. E-mail: wellington.araujo@ufrr.br

3 Prof ${ }^{a}$ Adjunta, Universidade Federal de Roraima, UFRR, Boa Vista, RR, Brasil. E-mail: pollyana.chagas@ufrr.br

4 Pesquisador, Empresa Brasileira de Pesquisa Agropecuária, EMBRAPA RORAIMA, Boa Vista, RR, Brasil. E-mail: edvan.chagas@ embrapa.br

5 Prof. Auxiliar, Universidad Nacional Autónoma de Chota, UNACH, Chota, CJ, Peru. E-mail: leohmurga@gmail.com

6 Pesquisador, Palmas del Espino S/A, PDE, Uchiza, SM, Peru. E-mail: rbardaleslozano@yahoo.es

7 Pesquisador, Instituto de Investigaciones de la Amazonía Peruana, IIAP, Yarinacocha, UC, Peru. E-mail: cabanto@iiap.gob.pe

Author for correspondence
} 
(A2) ChromatiNet ${ }^{\circledR}$ vermelha 50\%; (A3) ChromatiNet $^{\circledR}$ vermelha 35\% e (A4) ChromatiNet ${ }^{\circledR}$ Silver 35\%] associados a quatro substratos [(S1) solo + areia + esterco de galinha; (S2) solo + areia + esterco bovino; (S3) solo + areia + esterco bovino + esterco de galinha e (S4) solo + areia + esterco de ovino]. Instalouse um experimento inteiramente ao acaso, com tratamentos arranjados em parcelas subdivididas, com quatro repetições e dez plantas por unidade experimental, sendo analisadas as variáveis de crescimento e os índices de qualidade das mudas. Os ambientes testados aumentaram a temperatura local em relação ao ambiente externo, sendo uma influência negativa para o crescimento das plantas. O ambiente A2 promoveu os maiores valores de altura e massa seca das plantas, porém com crescimento irregular entre as partes vegetais avaliadas. O substrato confeccionado com esterco ovino (S4) não favoreceu a produção das mudas avaliadas. Os substratos S2 [solo + areia + esterco bovino] e S3 [solo + areia + esterco bovino + esterco de galinha] promoveram os melhores resultados de crescimento e de qualidade das mudas, sendo, portanto, promissores à produção de mudas de Annona squamosa L. no Cerrado de Roraima.

Palavras-chave: Annonaceae. Propagação. Telas de sombreamento.

\section{Introduction}

Annona squamosa L., commonly known as sugar apple or sweetsop, is one of the most widely grown members of the Annonaceae family in the world. In Brazil, because of its high commercial acceptance, its production is undergoing expansion, with plantations for fresh fruit production almost entirely destined for the internal market (SÃO JOSÉ et al., 2014).

Due to local climatic conditions, which benefit its production, A. squamosa has been piquing the interest of producers in the state of Roraima, Northern Brazil. These climatic conditions warrant the establishment of new orchards to meet the local demand for sugar apples (CHAGAS et al., 2013a). However, these conditions need to be used in conjunction with technologies and management practices that maximize their potential in the region.

For seedling production, environments that provide optimal conditions for plant light use are essential for photosynthetic processes, since the intensity and spectral quality of solar radiation strongly influence plant morphological development (STAMPS, 2009). It should be highlighted that excess radiation, typical of the Roraima Cerrado (ARAÚJO et al., 2001), may cause partial or total scorching of seedlings, thus requiring the adoption of technologies that promote the efficient use of available light energy.
Environments covered by shade nets have been widely used in commercial nurseries for fruit or ornamental plant seedlings. The use of ChromatiNet $^{\circledR}$ shade nets of different colors may be a viable alternative, depending on the crop and color (SHAHAK et al., 2004). Shade nets are a possible alternative to manage the incident light spectrum because they can change the amount and quality of solar radiation transmitted, therefore changing diffusion and reflectance, promoting the transmittance of light energy that can be used by seedlings (CHAGAS et al., 2013b).

In addition to the environment, the use of substrates that supply nutrients, water, and oxygen to plants is an essential factor in seedling production. Substrates should be selected based on their physical and chemical characteristics, $\mathrm{pH}$, the plant species that they will be used to grow, absence of chemical elements at toxic levels, adequate electrical conductivity, and economic factors, since substrates represent a high percentage of the seedling production costs (WELTER et al., 2011).

The aim of the present study was to evaluate the production of Annona squamosa L. seedlings in different substrates under shade nets in the environmental conditions of Roraima Cerrado. 


\section{Material and Methods}

Study site

The experiment was performed in the experimental area of the Agricultural Science Center of the Federal University of Roraima (Universidade Federal de Roraima - UFRR), in the municipality of Boa Vista, Roraima, Brazil (2'49'11'N, $60^{\circ} 40^{\prime} 24^{\prime \prime} \mathrm{W}$, altitude $90 \mathrm{~m}$ ). According to the Köppen climate classification, the region's climate is Awi, with two well defined seasons (a rainy season from April to September, and a dry season from October to March), and an average annual rainfall, relative humidity, and temperature of 1.678 $\mathrm{mm}, 70 \%$, and $27.4^{\circ} \mathrm{C}$, respectively (ARAÚJO et al., 2001). During the experiment, the temperature of the different environments was measured daily at the following four time points: 09:00, 11:00, 13:00, and 15:00.

\section{Plant material}

Sugar apple seedlings were produced by seminiferous propagation, using healthy and ripe fruits collected from a commercial orchard at the municipality of Maria Helena, Paraná, Brazil. After fruit collection, seeds were manually removed and washed in running water until all pulp residues were eliminated. The seeds were then standardized for size and immersed in gibberellic acid (GE3) (100 mg L ${ }^{-1}$ GE3) for 12 hours to overcome dormancy (SOUZA et al., 2008).

Seeds were sown in polyethylene bags $(0.15 \mathrm{x}$ $0.225 \mathrm{~m}$ ), with three seeds per bag. Fifteen days after sowing, the seedlings were thinned, leaving only the most developed seedlings, and were placed in benches $(15 \mathrm{~m}$ length $\mathrm{x} 1.20 \mathrm{~m}$ width $\mathrm{x} 0.8 \mathrm{~m}$ height) in closed, screened nurseries measuring $17 \mathrm{~m}$ in length, $4 \mathrm{~m}$ in width, and $2.5 \mathrm{~m}$ in height. Plants were irrigated twice daily every other day for 20 minutes using a micro-sprinkler system with a flow rate of $8 \mathrm{~L} \mathrm{~h}^{-1}$ and an irrigation frequency of four times a day for 15 minutes. Weed control was performed mechanically, by manual pulling, as needed.

\section{Experimental design}

A completely randomized experimental design was used, with treatments in a split-plot arrangement, in four nurseries covered with different shade nets (plots) in combination with four different substrates (subplots), with four replicates. Each experimental unit consisted of ten plants.

The nurseries consisted of a wooden structure measuring $17 \mathrm{~m}$ in length, $4 \mathrm{~m}$ in width and 2.5 $\mathrm{m}$ in height covered with a shade net. Nurseries were completely closed and equipped with benches measuring $15 \mathrm{~m}$ in length, $1.20 \mathrm{~m}$ in width, and 0.8 $\mathrm{m}$ in height. The following light environments were tested: E1) silver shade net with 50\% light reduction (ChromatiNet ${ }^{\circledR}$ Silver); E2) red shade net with 50\% light reduction (ChromatiNet ${ }^{\circledR}$ Red); E3) red shade net with $35 \%$ light reduction (CV); and E4) silver shade net with 35\% light reduction (CS).

The following four substrate compositions were also tested: $\mathrm{S} 1)$ soil + sand + chicken manure $(3: 1: 1$, $\mathrm{v} / \mathrm{v}) ; \mathrm{S} 2)$ soil + sand + cattle manure $(3: 1: 1, \mathrm{v} / \mathrm{v})$; S3) soil + sand + cattle manure + chicken manure $(3: 1: 0.5: 0.5, \mathrm{v} / \mathrm{v}) ; \mathrm{S} 4$ : soil + sand + sheep manure $(3: 1: 1, \mathrm{v} / \mathrm{v})$. The soil used for substrate preparation was a typical distrocohesive yellow Latosol (LAdx) obtained close to the experimental site. The sand used had medium grain size and was locally bought, and the manures were acquired from breeders from the municipality of Boa Vista. To all substrates, 2.0 $\mathrm{kg}$ of single superphosphate, $1.0 \mathrm{~kg}$ of potassium chloride, and $1.5 \mathrm{~kg}$ of dolomitic lime were added per $\mathrm{m}^{3}$ of substrate, according to the methodology proposed by Costa et al. (2013). The soil and substrate chemical characteristics are presented in Table 1. 
Table 1. Chemical characteristics of the soil and substrates used for the production of $A$. squamosa seedlings.

\begin{tabular}{|c|c|c|c|c|c|c|c|c|c|c|c|}
\hline \multirow{2}{*}{ Subst. } & \multirow{2}{*}{$\mathrm{pH}$} & $\mathrm{CE} 2^{+}$ & $\mathrm{Mg}^{2+}$ & $\mathrm{K}^{+}$ & $\mathrm{Al}^{2+}$ & $\mathrm{H}+\mathrm{Al}^{3+}$ & SB & $\mathrm{T}$ & \multirow{2}{*}{$\begin{array}{c}\mathrm{V} \\
\% \\
\end{array}$} & \multirow{2}{*}{$\begin{array}{c}\mathrm{OM} \\
\mathrm{g} \mathrm{dm}^{-3}\end{array}$} & \multirow{2}{*}{$\frac{\mathrm{P}}{\mathrm{mg} \mathrm{dm^{-3 }}}$} \\
\hline & & \multicolumn{7}{|c|}{ 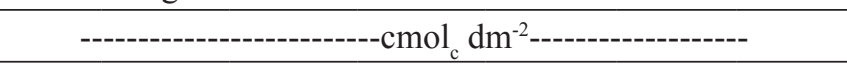 } & & & \\
\hline Soil & 5.4 & 0.3 & 0.3 & 0.07 & 0.4 & 2.08 & 0.67 & 2.75 & 24.24 & 8.6 & 2.30 \\
\hline S1 & 7.1 & 2.1 & 1.2 & 2.20 & - & 1.19 & 5.51 & 6.70 & 82.17 & 22.3 & 592.8 \\
\hline $\mathrm{S} 2$ & 7.0 & 2.0 & 1.5 & 2.35 & - & 1.07 & 5.86 & 6.93 & 84.55 & 34.1 & 498.5 \\
\hline $\mathrm{S} 3$ & 7.5 & 1.5 & 1.5 & 2.53 & - & 0.95 & 5.54 & 6.49 & 85.34 & 32.8 & 436.9 \\
\hline S4 & 6.8 & 2.9 & 2.6 & 2.40 & - & 1.49 & 7.91 & 9.40 & 84.15 & 28.7 & 543.0 \\
\hline
\end{tabular}

S1: soil + sand + chicken manure $(3: 1: 1 \mathrm{v} / \mathrm{v}) ; \mathrm{S} 2:$ soil + sand + cattle manure $(3: 1: 1 \mathrm{v} / \mathrm{v}) ; \mathrm{S} 3:$ soil + sand + cattle manure + chicken manure $(3: 1: 0.5: 0.5 \mathrm{v} / \mathrm{v}) ; \mathrm{S} 4:$ soil + sand + sheep manure $(3: 1: 1 \mathrm{v} / \mathrm{v})$.

\section{Parameters evaluated}

The following seedling growth parameters were evaluated 75 days after emergence (DAE): number of leaves (NL), plant height (PH), stem diameter (SD), root length (RL), shoot dry weight (SDW), and root dry weight (RDW). NL was determined by counting the number of fully expanded leaves. PH and RL were measured using a graded ruler, and RL was measured from a seedling's base to its apex. SD was measured using a precision digital pachymeter. SDW and RDW were measured after drying the seedlings in a forced air circulation oven at $70^{\circ} \mathrm{C}$ for 72 hours.

Two seedling growth quality indices were calculated: plant height/stem diameter ratio $(\mathrm{PH} /$ SD) and Dickson quality index (DQI), calculated as: $\mathrm{DQI}=\mathrm{TDW} /(\mathrm{PH} / \mathrm{SD}+\mathrm{SDW} / \mathrm{RDW})$.

\section{Data analysis}

Normality was tested using the KolmogorovSmirnov test. When normality was verified, an analysis of variance was performed, and when significant effects were observed, averages were compared using the Scott-Knott test. All statistical analyses were performed using the SISVAR 5.1 software (FERREIRA, 2011).

\section{Results and Discussion}

The tested environments significantly increased the average local temperature during the experimental period (Table 2), indicating that the shade nets directly affected the formation of microclimates for production of sugar apple seedlings, which may directly affect plant development during the early growth stage. Temperature was higher in environments with $50 \%$ light reduction at all measurement times, indicating that ambient temperature increase depended on the level of shade more than the type of shade net used. These results are in agreement with previously reported direct effects of temperature, since temperature is one of the most detrimental abiotic factors to plant growth. 
Table 2. Average ambient temperature $\left({ }^{\circ} \mathrm{C}\right)$ under different treatments during the experiment.

\begin{tabular}{lllllc}
\hline \multirow{2}{*}{ Environment } & \multicolumn{5}{c}{ Average temperature $\left({ }^{\circ} \mathrm{C}\right)$} \\
\cline { 2 - 6 } & $09: 00$ & $11: 00$ & $13: 00$ & $15: 00$ & Average \\
\hline (E1) Silver 50\% & 29.07 & 32.40 & 33.82 & 30.44 & 31.43 \\
(E2) Red 50\% & 30.23 & 32.81 & 34.03 & 31.83 & 32.23 \\
(E3) Red 35\% & 28.55 & 32.02 & 33.15 & 29.51 & 30.81 \\
(E4) Silver 35\% & 28.11 & 32.12 & 33.22 & 28.52 & 30.49 \\
(AE) External environment & 28.91 & 22.16 & 33.63 & 29.54 & 28.56 \\
\hline
\end{tabular}

A significant $\mathrm{E} \times \mathrm{S}$ interaction was observed for variables $\mathrm{PH}, \mathrm{NL}, \mathrm{RL}$, and $\mathrm{PH} / \mathrm{SD}$ (Table 3). SD was not affected by treatment, and was $5.9 \mathrm{~mm}$ per plant on average. Single effects of environment and substrate (SDW) or of substrate only (RDW and DQI) were observed for the remaining variables, indicating that they were not affected by the joint effect of environment and substrate.

Table 3. Summary of the analysis of variance for plant height (PH), number of leaves (NL), stem diameter (SD), root length (RL), shoot dry weight (SDW), root dry weight (RDW), plant height/stem diameter ratio (PH/SD), and Dickson quality index (DQI) of sugar apple seedlings produced under different environments and with different substrates.

\begin{tabular}{cccccccccc}
\hline \multirow{2}{*}{ VF } & \multirow{2}{*}{ DF } & \multicolumn{8}{c}{ F test } \\
\cline { 3 - 9 } & & PH & NL & SD & RL & SDW & RDW & PH/SD & DQI \\
\hline Environment (E) & 3 & $663.7^{* *}$ & $30.8^{* *}$ & $0.1^{\text {ns }}$ & $1.3^{\text {ns }}$ & $8.9^{* *}$ & $1.6^{\text {ns }}$ & $265^{* *}$ & $1.5^{\text {ns }}$ \\
Substrate (S) & 3 & $86.5^{* *}$ & $6.4^{* *}$ & $1.6^{\text {ns }}$ & $10.4^{* *}$ & $6.6^{* *}$ & $3.6^{*}$ & $9.7^{* *}$ & $3.9^{*}$ \\
E x S & 9 & $84^{* *}$ & $2.7^{* *}$ & $1.1^{\text {ns }}$ & $5.2^{* *}$ & $2.0^{\text {ns }}$ & $0.6^{\text {ns }}$ & $12.2^{* *}$ & $1.0^{\text {ns }}$ \\
CV1 (\%) & & 3.2 & 3.9 & 8.8 & 20.4 & 21.7 & 49.6 & 4.97 & 30.5 \\
CV2 (\%) & & 2.4 & 4.1 & 8.1 & 14.7 & 17.9 & 47.1 & 6.16 & 30.3 \\
\hline Average & & 46.0 & 19.9 & 5.9 & 25.6 & 4.21 & 1.92 & 78.18 & 0.6 \\
\hline
\end{tabular}

ns, * ** - non-significant, significant at $\mathrm{p} \leq 0.05$ and $\mathrm{p} \leq 0.01$, respectively, according to the $\mathrm{F}$ test.

The slicing of the interactions for PH, NL, and RL revealed variation in environments within substrate levels and in substrates within environment levels, resulting in environment E2 and substrates $\mathrm{S} 1$ and $\mathrm{S} 3$. Environment E2 had the strongest effect on $\mathrm{PH}$, independent of the substrate used. S3 combined with environments E2 $(63.39 \mathrm{~cm})$ and E4 $(50.50$ $\mathrm{cm})$, and $\mathrm{S} 2$ combined with E1 $(52.87 \mathrm{~cm})$, were the substrates with the strongest positive effect on seedling growth (Table 4). 
Table 4. Average plant height (PH), number of leaves (NL), and root length (RL) of sugar apple seedlings produced under different environments and with different substrates.

\begin{tabular}{cccccc}
\hline \multicolumn{5}{c}{ Plant height $(\mathrm{cm})$} \\
\hline Treatment & $\mathrm{E} 1$ & $\mathrm{E} 2$ & $\mathrm{E} 3$ & $\mathrm{E} 4$ & Average \\
$\mathrm{S} 1$ & $47.65 \mathrm{Bb}$ & $59.26 \mathrm{Ba}$ & $40.71 \mathrm{Ad}$ & $45.67 \mathrm{Bc}$ & 48.32 \\
$\mathrm{~S} 2$ & $52.87 \mathrm{Aa}$ & $52.79 \mathrm{Ca}$ & $24.99 \mathrm{Dc}$ & $44.90 \mathrm{Bb}$ & 43.90 \\
$\mathrm{~S} 3$ & $46.50 \mathrm{Bc}$ & $63.39 \mathrm{Aa}$ & $32.29 \mathrm{Cd}$ & $50.50 \mathrm{Ab}$ & 48.18 \\
S4 & $41.31 \mathrm{Cc}$ & $51.53 \mathrm{Ca}$ & $35.83 \mathrm{Bd}$ & $46.1 \mathrm{Bb}$ & 43.70 \\
\hline Average & 47.08 & 56.74 & 33.46 & 46.81 & \\
\hline \multicolumn{5}{c}{$\mathrm{Number}$ of leaves } \\
\hline Treatment & $\mathrm{E} 1$ & $\mathrm{E} 2$ & $\mathrm{E} 3$ & Average \\
S1 & $20.76 \mathrm{Aa}$ & $21.34 \mathrm{Aa}$ & $20.46 \mathrm{Aa}$ & $20.73 \mathrm{Aa}$ & 20.82 \\
S2 & $19.81 \mathrm{Aa}$ & $20.15 \mathrm{Aa}$ & $16.94 \mathrm{Cb}$ & $20.44 \mathrm{Aa}$ & 19.34 \\
S3 & $20.02 \mathrm{Aa}$ & $21.33 \mathrm{Aa}$ & $17.60 \mathrm{Cc}$ & $20.36 \mathrm{Aa}$ & 19.83 \\
S4 & $18.53 \mathrm{Bb}$ & $20.91 \mathrm{Aa}$ & $18.94 \mathrm{Bb}$ & $20.49 \mathrm{Aa}$ & 19.72 \\
\hline Average & 19.78 & 20.93 & 18.48 & 20.50 & \\
\hline \multicolumn{7}{c}{$\mathrm{Root}$ length $(\mathrm{cm})$} & $\mathrm{E} 4$ & Average \\
\hline Treatments & $\mathrm{E} 1$ & $\mathrm{E} 2$ & $\mathrm{E} 3$ & 29.81 \\
S1 & $37.50 \mathrm{Aa}$ & $30.50 \mathrm{Ab}$ & $29.75 \mathrm{Ab}$ & $21.51 \mathrm{Bc}$ & 25.56 \\
S2 & $24.00 \mathrm{Ba}$ & $24.00 \mathrm{Ba}$ & $25.00 \mathrm{Ba}$ & $29.25 \mathrm{Aa}$ & 24.13 \\
S3 & $24.75 \mathrm{Bb}$ & $29.50 \mathrm{Aa}$ & $21.25 \mathrm{Bb}$ & $21.25 \mathrm{Bb}$ & 22.81 \\
S4 & $22.25 \mathrm{Bb}$ & $22.00 \mathrm{Ba}$ & $23.50 \mathrm{Ba}$ & $23.50 \mathrm{Ba}$ & \\
\hline Average & 27.13 & 26.44 & 24.88 & 23.88 &
\end{tabular}

Averages followed by the same lowercase letter within the same line and uppercase letter within the same column are not statistically significantly different according to the Scott-Knott test ( $\mathrm{p}>0.05)$.

The levels of significance were lower for NL than for $\mathrm{PH}$, because the substrates and environments presented lower statistical variation, showing that NL was less affected by the treatments than PH. NL was lower in E3, for all substrates, than the remaining environments, which were not significantly different from each other. Among the environments with higher NL values (E1, E2, and E4), no significant differences were observed between substrates except for S4 combined with E1, which resulted in lower NL than the remaining treatments (Table 4).
RL was higher in S1 combined with E1 (37.5 $\mathrm{cm})$, E2 $(30.5 \mathrm{~cm})$, and E3 $(29.8 \mathrm{~cm})$, in $\mathrm{S} 2$ combined with E4 $(29.3 \mathrm{~cm})$, and in S3 combined with E2 $(29.5 \mathrm{~cm})$. SDW was affected by percentage light reduction, independent of screen color, and was higher in E1 and E2 (50\% light reduction). Regarding the substrate effect, SDW did not differ significantly between $\mathrm{S} 1, \mathrm{~S} 2$, and $\mathrm{S} 3$, and was lower in S4 (Table 5). 
Table 5. Average shoot dry weight (SDW), root dry weight (RDW), plant height/stem diameter ratio (PH/SD), and Dickson quality Index (DQI) of sugar apple seedlings produced under different environments and with different substrates.

\begin{tabular}{|c|c|c|c|c|c|}
\hline \multicolumn{6}{|c|}{ Shoot dry weight (g) } \\
\hline Treatments & E1 & E2 & E3 & E4 & Average \\
\hline S1 & 4.58 & 4.84 & 4.83 & 3.84 & $4.53 \mathrm{~A}$ \\
\hline S2 & 4.54 & 5.42 & 3.14 & 3.50 & $4.15 \mathrm{~A}$ \\
\hline S3 & 5.64 & 5.65 & 3.45 & 3.73 & $4.62 \mathrm{~A}$ \\
\hline S4 & 4.17 & 3.95 & 3.22 & 2.86 & $3.56 \mathrm{~B}$ \\
\hline Average & $4.74 \mathrm{a}$ & $4.97 \mathrm{a}$ & $3.66 \mathrm{~b}$ & $3.49 \mathrm{~b}$ & \\
\hline \multicolumn{6}{|c|}{ Root dry weight $(\mathrm{g})$} \\
\hline Treatments & E1 & E2 & E3 & E4 & Average \\
\hline S1 & 1.75 & 1.51 & 1.74 & 1.96 & $1.74 \mathrm{~B}$ \\
\hline S2 & 2.14 & 2.18 & 1.61 & 1.77 & $1.93 \mathrm{~B}$ \\
\hline S3 & 3.05 & 2.02 & 1.75 & 3.16 & $2.50 \mathrm{~A}$ \\
\hline S4 & 1.54 & 1.47 & 1.00 & 1.98 & $1.50 \mathrm{~B}$ \\
\hline Average & 2.12 & 1.80 & 1.53 & 2.22 & \\
\hline \multicolumn{6}{|c|}{$\mathrm{PH} / \mathrm{SD}$} \\
\hline Treatments & E1 & E2 & E3 & E4 & Average \\
\hline S1 & $80.73 \mathrm{Bb}$ & $102.96 \mathrm{Aa}$ & $70.54 \mathrm{Ac}$ & $76.35 \mathrm{Bb}$ & 82.65 \\
\hline S2 & $89.08 \mathrm{Aa}$ & $91.51 \mathrm{Ba}$ & $47.05 \mathrm{Cc}$ & $74.59 \mathrm{Bb}$ & 75.56 \\
\hline S3 & $74.81 \mathrm{Cc}$ & $103.86 \mathrm{Aa}$ & $52.78 \mathrm{Cd}$ & $88.07 \mathrm{Ab}$ & 79.88 \\
\hline $\mathrm{S} 4$ & $71.05 \mathrm{Cc}$ & $87.78 \mathrm{Ba}$ & $61.14 \mathrm{Bd}$ & $78.64 \mathrm{Bb}$ & 74.64 \\
\hline Average & 78.92 & 96.51 & 57.87 & 79.41 & \\
\hline \multicolumn{6}{|c|}{ DQI } \\
\hline Treatments & E1 & E2 & E3 & E4 & Average \\
\hline S1 & 0.58 & 0.47 & 0.67 & 0.60 & $0.58 \mathrm{~B}$ \\
\hline S2 & 0.59 & 0.65 & 0.71 & 0.55 & $0.63 \mathrm{~A}$ \\
\hline S3 & 0.93 & 0.57 & 0.68 & 0.68 & $0.72 \mathrm{~A}$ \\
\hline S4 & 0.58 & 0.47 & 0.44 & 0.51 & $0.50 \mathrm{~B}$ \\
\hline Average & 0.67 & 0.54 & 0.63 & 0.59 & \\
\hline
\end{tabular}

Averages followed by the same lowercase letter within the same line and uppercase letter within the same column are not statistically significantly different according to the Scott-Knott test $(\mathrm{p}>0.05)$.

RDW was not affected by the environment, but was significantly higher in S3 than in the remaining substrates (Table 5). This showed that RDW was not dependent on RL, since the substrates that resulted in the highest root length (Table 4) were not the same as those that resulted in the highest dry weight (S3) (Table 5). This indicated that RL may be inversely proportional to RDW.
Regarding the seedling growth quality indices, $\mathrm{PH}$ and $\mathrm{NL}, \mathrm{PH} / \mathrm{SD}$ was highest in $\mathrm{E} 2$ with all substrates, in S2 combined with $\mathrm{E} 1$, and in $\mathrm{S} 3$ combined with E4, indicating that shoot growth was less proportional to SD under the aforementioned conditions than under the remaining treatments. DQI, which reflects the uniform growth of all seedling vegetative components, was only affected 
by substrate, being higher in S2 and S3 than in S1 and $\mathrm{S} 4$, indicating that these substrates may be more suitable for sugar apple seedling production.

The considerable increase in ambient temperature promoted by the shade nets relative to the external environment may have been due to low circulation of hot air accumulating inside the nurseries (ROCHA, 2007) since they had no structure for its expulsion. This was confirmed by Monteiro Neto et al. (2018) for tomato seedling production, who observed decreased seedling quality with increased internal temperature in these environments.

Based on the present results, it should be highlighted that local temperature needs to be correctly managed for seedling production, since it may directly affect plant metabolism. Temperature interferes with the enzymatic activities (BELETI et al., 2012) and photosynthetic capacities (SHIMADA et al., 2017) of several plant species. The damage caused by high temperatures are reflected in chlorophyll fluorescence levels, since plants subjected to high temperatures present decreased photochemical quenching and increased non-photochemical quenching, decreasing the quantum efficiency of photosystem II (PSII) (XU et al., 2014). Losses in PSII efficiency lead to decreased function of the Cyt $\mathrm{b}_{6} \mathrm{f}$ complex, and consequently of photosystem I (PSI), resulting in the non-production of ATP and NADPH for the remaining photosynthetic processes (SHIMADA et al., 2017), which directly affects plant growth (TAIZ; ZAIGER, 2013).

In addition to temperature, the quantity and quality of solar radiation reaching the plants is a determining factor in seedling development and should be quantified in these types of environments. However, they were not evaluated in the present study. Monteiro Neto et al. (2018) studied tomato seedling production using the same environments tested in the present study, and measured global radiation (GR), photosynthetically active radiation (PAR), and PAR/GR ratio under the shade nets, and observed that shade nets with 35\% light reduction (E3 and E4) had in greater GR and PAR transmittance, but that the highest $\mathrm{PAR} / \mathrm{GR}$ ratio was observed under a red shade net with $50 \%$ light reduction (E2), which may have contributed to increased PH, NL, SDW, and RDW when analyzed alone.

PAR is the fraction of GR that includes the spectral range (wave band) of solar radiation from 400 to 700 $\mathrm{nm}$, and is directly linked to photochemical events in plants. Higher PAR relative to GR indicates that the environment retains more energy that the plant needs for its metabolism (TAIZ; ZAIGER, 2013). Under tropical climatic conditions such as those in the present study region, excess radiation and high temperatures are often the main limiting factors of crop growth and productivity, due to increased transpiration rate and stomatal closure, which decrease the rate of photosynthesis and subsequently negatively affect seedling development (WAHID et al., 2007).

These factors may be connected to the results of the present study as the plants presented somewhat uneven vegetative growth, especially as indicated by the $\mathrm{PH} / \mathrm{SD}$ value in $\mathrm{E} 2$, which also resulted in higher values for several of the variables evaluated (Tables 4 and 5). Similar behavior was also observed in pepper (MONTEIRO NETO et al., 2016) and tomato seedlings (MONTEIRO NETO et al., 2018), indicating that the tested shade nets promote uneven growth of the vegetative parts of a variety of plant species during seedling production.

It should be highlighted that seedling selection for planting based only on size or biomass may lead to the selection of bigger plants that are not able to sustain themselves in field plantations. For this reason, growth quality indices, such as DQI and $\mathrm{PH} /$ SD ratio, should be adopted.

The $\mathrm{PH} / \mathrm{SD}$ ratio indicates whether plant growth accompanies stem diameter growth, and is an estimator of plant survival in the field (RODRIGUES et al., 2010). Plants with higher SD relative to $\mathrm{PH}$ 
have higher survival chances after transplant, i.e., lower $\mathrm{PH} / \mathrm{SD}$ indicate higher chances of seedlings surviving at the final planting site. This may not happen for seedlings produced in environment E2, although they presented higher PH and SDW.

These results confirm those found for DQI, since no statistically significant differences were observed between environments (Table 5). DQI is widely used for the selection of high-quality seedlings because it integrates the morphological variables of plant height, diameter, and biomass into a weighed equation (BEZERRA et al., 2019). The higher the DQI, the more uniform the plant growth, which was observed in substrates S2 and S3.

Overall, the substrates with chicken and cattle manure presented better results than those that contained sheep manure, especially S2 (soil + sand + cattle manure) and S3 (soil + sand + cattle manure + chicken manure). This may be related to the possible fast nitrogen $(\mathrm{N})$ availability in these substrates, as reported by Melo et al. (2008), who observed high mineral $\mathrm{N}$ concentrations $\left(\mathrm{N}-\mathrm{NH}_{4}{ }^{+}\right.$ and $\mathrm{N}-\mathrm{NO}_{3}{ }^{-}$) in substrates similar to those tested in the present study.

The low seedling performance observed for the substrate with sheep manure may be related to the low decomposition and mineralization characteristics of this manure, since the speed of organic residue decomposition and consequent mineralization interferes with nutrient availability to plants (MELO et al., 2008; PEIXOTO FILHO et al., 2013).

Although there were promising results regarding the use of shade nets for seedling production, the present study shows the need for preliminary tests of their efficiency in naturally hot regions. This is especially true for large-scale production of commercial seedlings, since the costs of setting up these environments significantly weighs on the production.

\section{Conclusions}

Greenhouses made with shade nets may increase ambient temperature and negatively affect the quality of $A$. squamosa seedlings produced under the conditions of the Roraima Cerrado.

Substrates consisting of soil + sand + cattle manure $(3: 1: 1 \mathrm{v} / \mathrm{v})$ and soil + sand + cattle manure + chicken manure (3:1:0.5:0.5 v/v) are promising for the production of $A$. squamosa seedlings.

\section{References}

ARAÚJO, W. F.; ANDRADE JÚNIOR, A. S.; MEDEIROS, R. D.; SAMPAIO, R. A. Precipitação pluviométrica provável em Boa Vista, Estado de Roraima, Brasil. Revista Brasileira de Engenharia Agrícola e Ambiental, Campina Grande, v. 5, n. 3, p. 563-567, 2001. DOI: $10.1590 / \mathrm{S} 1415-43662001000300032$

BELETI, M. A.; DUARTE, F.; GEORG-KRAEMER, J. E. A temperatura no desenvolvimento da atividade das enzimas (1-3, 1-4)- $\beta$-glucanases e degradação de $\beta$-glucanos durante a malteação. Ciência Rural, Santa Maria, v. 42, n. 3, p. 467-473, 2012. DOI: $10.1590 /$ S0103-84782012000300013

BEZERRA, M. A. F.; PEREIRA, W. E.; BEZERRA, F. T. C.; CAVALCANTE, L. F.; MEDEIROS, S. A. S. Nitrogen as a mitigator of salt stress in yellow passion fruit seedlings. Semina: Ciências Agrárias, Londrina, v. 40, n. 2, p. 611622, 2019. DOI: 10.5433/1679-0359.2019v40n2p611

CHAGAS, E. A.; RIBEIRO, M. I. G.; SOUZA, O. M.; SANTOS, V. A.; LOZANO, R. M. B.; BACELARLIMA, C. G. Alternatives substrates for production of seedlings camu-camu. Revista de Ciências Agrárias Amazonian Journal of Agricultural and Environmental Sciences, Belém, v. 56, p. 5-12, 2013a. Supplement. DOI: $10.4322 /$ rca.2013.074

CHAGAS, J. H.; PINTO, J. E. B. P.; BERTOLUCCI, S. K. V.; COSTA, A. G.; JESUS, H. C. R.; ALVES, P. B. Produção, teor e composição química do óleo essencial de hortelã-japonesa cultivada sob malhas fotoconversoras. Horticultura Brasileira, Brasília, v. 31, n. 2, p. 297-303, 2013b. DOI: 10.1590/S0102-05362013000200020

COSTA, E.; DURANTE, L. G. Y.; SANTOS, A.; FERREIRA, C. R. Production of eggplant from seedlings produced in different environments, containers and substrates. Horticultura Brasileira, Brasília, v. 31, n. 1, p. 139-143, 2013. DOI: 10.1590/S010205362013000100022 
FERREIRA, D. F. Sisvar: a computer statistical analysis system. Ciência e Agrotecnologia, Lavras, v. 35, n. 6, p. 1039-1042, 2011. DOI: 10.1590/S141370542011000600001

MElO, L. C. A.; SILVA, C. A.; DIAS, B. O. Caracterização da matriz orgânica de resíduos de origens diversificadas. Revista Brasileira de Ciência do Solo, Viçosa, MG, v. 32, n. 1, p. 101-110, 2008. DOI: 10.1590/ S0100-06832008000100010

MONTEIRO NETO, J. L. L.; ARAÚJO, W. F.; VILARINHO, L. B. O.; NUNES, T. K. O.; SILVA, E. S.; MAIS, S. S.; ALBUQUERQUE, J. A. A.; CHAGAS, E. A.; SIQUEIRA, R. H. S.; ABANTO-RODRIGUEZ, C. Producción de plántulas de dos cultivares de tomate (Solanum licopersicum L.) en diferentes ambientes y sustratos. Acta Agronómica, Palmira, v. 67, n. 2, p. $270-$ 276, 2018. DOI: 10.15446/acag.v67n2.67943

MONTEIRO NETO, J. L. L.; ARAÚJO, W. F.; VILARINHO, L. B. O.; SILVA, E. S.; ARAÚJO, W. B. L.; SAKAZAKI, R. T. Produção de mudas de pimentão (Capsicum annuum L.) em diferentes ambientes e substratos. Revista Brasileira de Ciências Agrárias, Recife, v. 11, n. 4, p. 289-297, 2016. DOI: 10.5039/ agraria.v11i4a5395

PEIXOTO FILHO, J. U.; FREIRE, M. B. G.; FREIRE, F. J.; MIRANDA, M. F. A.; PESSOA, L. G. M.; KAMIMURA, K. M. Produtividade de alface com doses de esterco de frango, bovino e ovino em cultivos sucessivos. Revista Brasileira de Engenharia Agrícola e Ambiental, Campina Grande, v. 17, n. 4, p. 419-424, 2013. DOI: $10.1590 / \mathrm{S} 1415-43662013000400010$

ROCHA, R. C. Uso de diferentes telas de sombreamento no cultivo protegido do tomateiro. 2007. Tese (Doutorado em Agronomia) - Universidade Estadual Paulista, Botucatu.

RODRIGUES, E. T.; LEAL, P. A. M.; COSTA, E.; PAULA, T. S.; GOMES, V. A. Produção de mudas de tomateiro em diferentes substratos e recipientes em ambiente protegido. Horticultura Brasileira, Brasília, v. 28, n. 4, p. 483-488, 2010. DOI: 10.1590/S010205362010000400018
SÃO JOSÉ, A. R.; PIRES, M. M.; FREITAS, A. L. F. E.; RIBEIRO, D. P.; PEREZ, L. A. A. Atualidades e perspectivas das Anonáceas no mundo. Revista Brasileira de Fruticultura, Jaboticabal, v. 36, p. 86-93, 2014. Edição Especial. DOI: 10.1590/S0100-29452014000500010

SHAHAK, Y.; GUSSAKOVSKY, E.; GAL, E.; GANELEVIN, R. ColorNets: crop protection and light quality manipulation in one technology. Acta Horticulturae, Amsterdam, v. 659, n. 1, p. 143-151, 2004. DOI: 10.17660/ActaHortic.2004.659.17

SHIMADA, A.; KUBO, T.; TOMINAGA, S.; YAMAMOTO, M. Effect of temperature on photosynthesis characteristics in the passion fruits Summer Queen and ruby Star. The Horticulture Journal, Yamaguchi, v. 86, n. 2, p. 194-199, 2017. DOI: 10.2503/ hortj.OKD-023

SOUZA, S. A.; DANTAS, A. C. V. L.; PELACANI, C. R.; VIEIRA, E. L.; LEDO, C. A. S. Superação da dormência em sementes de pinha. Revista Caatinga, Mossoró, v. 21, n. 4, p. 118-121, 2008.

STAMPS, R. H. Use of colored shade netting in horticulture. HortScience, Alexandria, v. 44, n. 2, p. 239241, 2009. DOI: 10.21273/HORTSCI.44.2.239

TAIZ, L.; ZEIGER, E. Fisiologia vegetal. 5. ed. Porto Alegre: Artemed, 2013. 954 p.

WAHID, A.; GELANI, S.; ASHRAF, M.; FOOLAD, M. R. Heat tolerance in plants: an overview. Environmental and Experimental Botany, Elmsford, v. 61, n. 3, p. 199223, 2007. DOI: 10.1016/j.envexpbot.2007.05.011

WELTER, M. K.; MELO, V. F.; BRUCKNER, C. H.; GÓES, H. T. P. D.; CHAGAS, E. A.; UCHÔA, S. C. P. Efeito da aplicação de pó de basalto no desenvolvimento inicial de mudas de camu-camu (Myrciaria dubia H.B.K. McVaugh). Revista Brasileira de Fruticultura, Jaboticabal, v. 33, n. 3, p. 922-931, 2011. DOI: 10.1590/ S0100-29452011000300028

XU, H.; LIU, G.; LIU, G.; YAN, B.; DUAN, W.; WANG, L.; LI, S. Comparison of investigation methods of heat injury in grapevine (Vitis) and assessment to heat tolerance in different cultivars and species. BMC Plant Biology, Londres, v. 14, n. 1, p. 156-165, 2014. DOI: 10.1186/1471-2229-14-156 